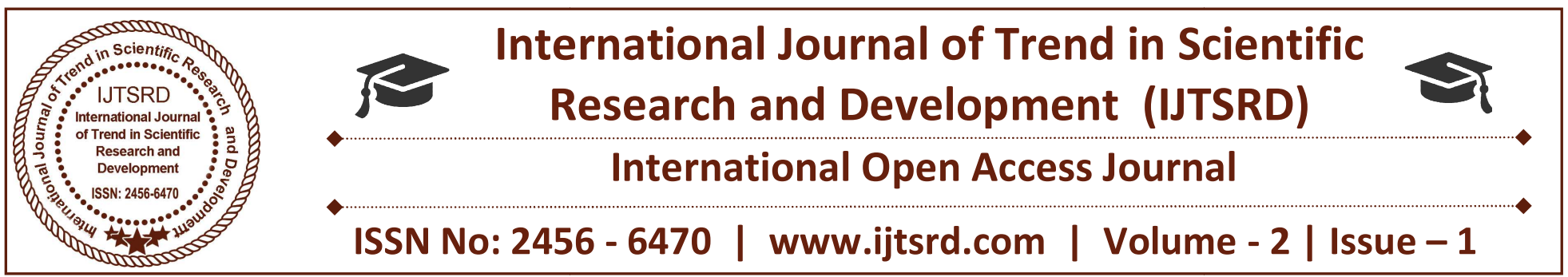

\title{
A Study on Housing Finance in India with Special Reference to LIC Housing Finance Limited
}

\author{
Dr Bandaru Appala Satya Murthy \\ Associate Professor, School of Management Studies- Mrpg College, \\ Phool Baugh Colony, Vizianagaram- 535002, Andhra Pradesh
}

\section{ABSTRACT}

Housing Finance in India during the last decade has gone through many changes. From very low exposure to the housing sector initially, banks have gone very fast in extending credit to this sector which has witnessed unprecedented expansion. With urbanization and higher level of economic growth, it is quiet natural that the housing sector has received a enormous growth. However, in the recent years the banks have gone faster than what could be a reasonably justified in financing this sector. At the international level, the speed at which banks have rushed to this sector, has resulted in financial crisis causing great damages to the stability of the banking system. Housing is one of the most important that we human beings need. Adequate housing is essential for human survival with dignity. There are many things that we would find difficult, if not impossible to do without good-quality housing. Housing shortage is an universal phenomenon. It is more acute in developing countries. The housing scenario has become more critical in India in recent years. India has initiated so many housing reform that has taken many forms and manifestations characterized by the reduction in social allocation, cutbacks in public funding and promotion of a real estate culture in close partnership between the state and private actors. Mortgage financing markets can play an important role in stimulating affordable housing markets and improving housing quality in many countries. Unfortunately, these are still in infancy in India. This lack of development often translates into lower homeownership rates or poor housing quality. Most of these problems stem from the central dilemma that the resources are always too limited and housing development heavily depend on the financial institutions such as banks, credit corporations and development banks for the supply of finance to meet their daily financial needs. Against this backdrop, this paper will assess basic hurdles of Indian financing system.

Keywords: Housing Sector, Housing Shortage, Mortgage, Housing market and Housing finance in India

\section{INTRODUCTION}

Real estate and dwellings has a share of 6.8 percent in India's GDP and a growth of 32.36 percent in 201415. The growth of real estate services in has been consistently impressive at over 31 percent since 2005 06 with32.3 percent growth in 2014-15. Housing is a basic necessity for human life and second largest generator of employment, next only to agriculture. Housing activities have both forward and backward linkages in nearly 450 sub-sectors such as manufacturing (steel, cement, and builders' hardware), transport, electricity, gas and water ,supply, trade, financial services, and construction which contribute to capital formation, income opportunities, and generation of employment. In 2012-13 property prices had begun to moderate. As per the National Housing Bank (NHB) RESIDEX index for the quarter July-September 2014 compared to April-June 2014 (covering 20 cities, with 2011 as base year), there is a general decline in prices of residential properties in some smaller towns (Tier-II \&III), while there is increase in some other cities which is marginal. In view of increased urbanization, the housing requirements in urban areas have been 
witnessing increase over the years. The Eleventh Five Year Plan (2007-12) estimated housing requirement of 24.7 million units in urban areas of which 99 percent was in the economically weaker sections(EWS)/lower income groups (LIG) segment. While these institutions largely cater to the formal sector, access to finance by the informal market segment largely remains untapped. As this untapped market segment is significant and growing, the Government of India has announced various measures like the Interest Subsidy Scheme for Housing for the Urban Poor and setting up of the Credit Risk Guarantee Fund Trust for Low Income Housing. With support from lending institutions, housing credit has grown substantially over the years, resulting in increased market penetration. The housing loan portfolio of scheduled commercial banks and housing finance companies- the major institutional players stood at 6.10lakh crore as in end-March 2012. However, due to limited housing finance solutions, the gap between housing demand and supply is widening. Besides the mortgage market in India is also underdeveloped. Though mortgages as a percentage of GDP have improved from 3.4 percent in 2001 to 9 percent in 2011-12, the share is relatively lower than in many other countries - such as China (12 percent), Thailand (17 percent), Hong Kong (40 percent), and the USA (65 percent). The NHB has also floated a joint-venture mortgage guarantee company- the India Mortgage Guarantee Corporation Pvt. Ltd-which will offer mortgage guarantees against borrower defaults on housing loans from mortgage lenders which will help expand access to housing in India.

\section{SIGNIFICANCE OF HOME LOANS}

Home loans, also known as mortgages, use the borrower's home for collateral. This home can be a single-family house up to a four-unit property, as well as a condominium or cooperative unit. Lenders fund home loans, but both the lenders themselves and brokers who act on behalf of the lenders originate, or process, them. Home loans came into widespread use in the United States in the boom years of the late 1800 s. Since the average person usually cannot afford to pay cash for something as expensive as a home, lenders began offering loans for the difference between the purchase price of a home and the cash down payment supplied by the buyer. These loans were interest-only loans of between five and ten years that were due in full at the end of the loan term. Homeowners would refinance the loan at the end of each term or save up enough cash to pay off the loan in the meantime. The Great Depression and its resulting foreclosures demanded a move to the modern amortized mortgage, which configures payments into both principal and interest portions. These 15- to 30-year loans pay off the home by the end of the loan term. According to the National Association of Home Builders, the housing industry as a whole contributes about 17 percent to 18 percent of the nation's GDP.

Table1: Housing Growth Trajectory

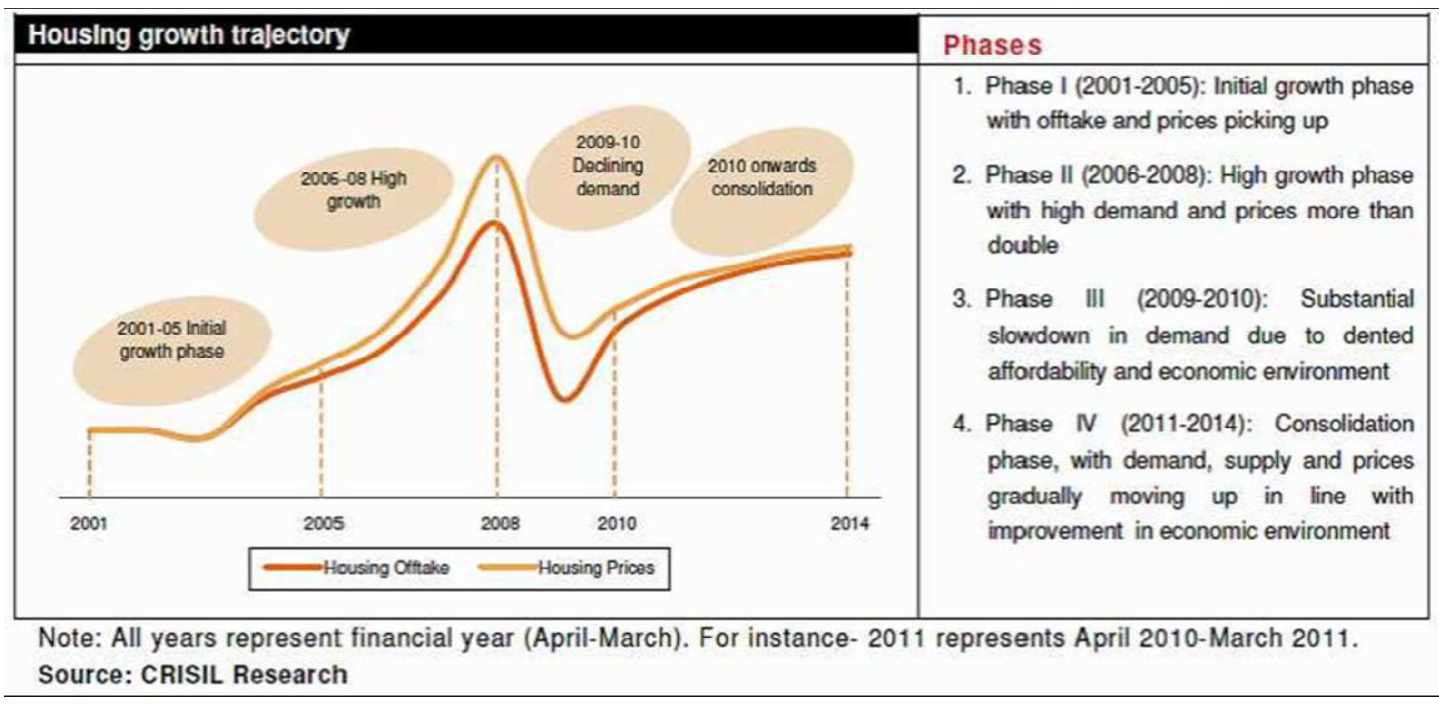


CASE REFERENCE: LIC HOUSING FINANCE LTD.

LIC is a Finance Company, Home Loan Providers In India at lowest interest Home Loans - With you for your dream home. Find easy Housing Loan for your needs from LIC Housing Finance at fixed \& Floating Rates. 5th largest lender in housing finance segment India. Recently cut it's Interest Rates by $0.40 \%$ on home Loans. New interest rates starting from 9.60 percent for loans up to Rs.3 crores

$>$ Interest Rates Starts from $8.50 \%$ to $8.90 \%$

More than 16.8 Lacs Customers

$>$ Offers Home Loans to Indians, NRI \& Pensioners.

$>$ Minimum loan Amount starts from Rs.1 Lakh

Loan Tenure: Maximum term - For Salaried 30 years, for self employed 20 Years

You can get loan for Construction, Purchase of Plot, Extension, Renovation, Flat Purchase Etc.

$>$ You can get up to $85 \%$ of total cost of property as loan amount.

LIC Housing Finance today launched 'New Advantage 5', a new home loan product that offers fixed rates of interest for the first five years and floating rates thereafter. The floating rates will be linked to the LHPLR (LIC HFL Prime Lending Rates) prevailing at the time of the switch, country's largest housing finance company said in a release issued here. For loans up to Rs 30 lakh, the fixed rate offered is 11.15 percent, for loan above Rs 30 lakh and less than Rs 75 lakh, rate is 11.40 percent and for loans of between Rs 75 lakh and Rs 150 lakh, the rate is 11.65 per cent, it said. The scheme is available till December 31 with a condition that the first disbursement should be availed by the customer on or before January 15, 2012. Taking a home loan nowadays has many advantages. Added to this, the RBI has been regularly slashing interest rates, with the result that housing finance loans that came at an interest rates. are now available at 8.35 percent to 9.5 percent or lower. Each year the Finance Minister's largesse during the Budget seems to be solely concentrated for the housing sector and construction sector. The Budget 2000's allowed interest payment up to Rs2.5 lakh and principal payment of Rs 20,000 to be exempted from income tax.

Here's why a loan from LIC Housing Finance Ltd. means a complete peace of mind

$>$ Lowest Interest Rates

$>$ Easy application, quick approvals.

$>$ Insurance - linked security.

$>$ Largest Network.

No Hidden Costs

A financially strong and stable company we have already sanctioned loans to more than 10 lakh applicants. With a network of more than 150 offices in the country we are always accessible to applicant, wherever applicant may be available.

\section{MEANING OF FLOATING \& FIXED RATE OF INTEREST}

Where the loan is under Floating Rate of Interest, the Rate of Interest are at present reviewed every three months ( January, April, July, October ) based on the prevailing market conditions as judged by the Company and LHPLR. The revised Floating Rate of Interest could increase, decrease or remain the same. However, the Rate of interest will be reviewed every 6 months (January, July) for old Customers as per their loan agreements

\section{PURPOSE OF HOMELOAN}

Home or housing loans are advances made to borrowers who require funds to purchase houses/flats/land. They can also be availed of for construction, extension, Plot Purchase, Flat, Villa and renovation of houses. Lenders can be banking or nonbanking financial institutions in India. Interest Rates Starts from 9.50 percent to 13.00 percent. Prepayment Charges for Home Loans are NIL. Processing Fees Varies from Bank to Banks (0.05\% $2.00 \%$ Range). Processing fees, pre-payment charges, inspection fees, documentation fees etc coming under Non Interest Category. Co- applicants/ Joint Applications are allowed. Borrowers are Qualify for tax benefits as per provisions of the IT Act, 1961 (subject to changes). The most common purpose of a home loan is to provide the funds a buyer needs to 
purchase a home. Home equity loans allow a homeowner to borrow against the difference between the home's value and the current loan balance, or equity. Investor loans permit buyers to purchase homes as rental properties or to fix up and sell at a profit.

\section{TYPES OF HOME LOANS}

The two most widely used types of home loans are fixed-rate loans and adjustable- rate loans. A fixedrate loan keeps the same interest rate for the life of the loan, which means that the principal and interest portions of the monthly payment stay the same. Adjustable-rate mortgages begin with a lower interest rate for the first few years and then adjust to market rates after the initial period is over. Caps are placed on how much the rate can adjust at any given time, as well as on how much the rate can increase over the duration of loan. This means the principal and interest portions of the monthly payment change repeatedly through the duration of loan. There are different types of home loans tailored to meet our needs. Here is a list of few:

Home Purchase Loans: This is the basic home loan for the purchase of a new home. Home Improvement Loans: These loans are given for implementing repair works and renovations in a home that has already been purchased.

Home Construction Loan: This loan is available for the construction of a new home. Home Extension Loan: This is given for expanding or extending an existing home. For eg: addition of an extra room etc.

Home Conversion Loan: This is available for those who have financed the present home with a home loan and wish to purchase and move to another home for which some extra funds are required. Through home conversion loan, the existing loan is transferred to the new home including the extra amount required, eliminating the need of pre-payment of the previous loan.

Land Purchase Loans: This loan is available for purchase of land for either construction or investment purposes.
Bridge Loans: Bridge loans are designed for people who wish to sell the existing home and purchase another one. The bridge loans help finance the new home, until a buyer is found for the home.

\section{EFFECTS OF HOME LOANS}

Because home loans are a large share of the financial situation of the majority of people, taking the time to determine the right type of loan and to investigate terms is essential for any home buyer or owner. Federal law promotes the consumer's ability to shop for the best loan by requiring lenders to give prospective borrowers Good Faith Estimates and Truth. In Lending (TIL) statements that disclose and itemize the terms and costs associated with a loan.

\section{PROCEDURE OF HOME LOAN}

With the increasing competition in the market for offering Home Loans, the otherwise tedious process of availing loans has gone a tremendous change in the recent years. However, there is still some process involved in the procurement of Home loan. It is advisable for borrower to first look at the different stages required for obtaining a Home Loan.

\section{Procedure:}

i: Application form

ii: Personal Discussion

iii: Bank's Field Investigation

iv: Credit appraisal by the bank and loan sanction

v: Offer Letter

vi: Submission of legal documents \& legal check

vii: Technical / Valuation check

viii: Registration of property documents

ix: Signing of agreements and submitting post-dated cheques

$\mathrm{x}$ : Disbursement 
Table2: Opportunity of housing business and Low income group of housing in India

\begin{tabular}{|c|c|c|c|c|c|c|c|}
\hline $\begin{array}{l}\text { Monthly } \\
\text { house hold } \\
\text { income }\end{array}$ & $\begin{array}{l}\text { Above } \\
50000\end{array}$ & $\begin{array}{l}40000- \\
50000\end{array}$ & $\begin{array}{l}30000- \\
40000\end{array}$ & $\begin{array}{l}20000- \\
30000\end{array}$ & $\begin{array}{l}10000- \\
20000\end{array}$ & $\begin{array}{l}5000- \\
10000\end{array}$ & Below 5000 \\
\hline $\begin{array}{l}\text { Housing } \\
\text { Demand(\%) }\end{array}$ & 01 & 05 & 04 & 05 & 21 & 31 & 33 \\
\hline $\begin{array}{l}\text { Price of } \\
\text { Dwelling Unit }\end{array}$ & \multicolumn{2}{|c|}{ Above Rs. 25 lakhs } & \multicolumn{2}{|c|}{ From Rs. 10-25 lakhs } & \multicolumn{3}{|c|}{ Below Rs. 10 lakhs } \\
\hline $\begin{array}{l}\text { Potential } \\
\text { Demand }\end{array}$ & \multicolumn{2}{|c|}{$\begin{array}{l}\text { Two million house } \\
\text { holds with estimated } \\
\text { market size of Rs. } \\
500,000 \text { crores }\end{array}$} & \multicolumn{2}{|c|}{$\begin{array}{l}\text { Five million house } \\
\text { holds with estimated } \\
\text { market size of Rs. } \\
900000 \text { crores }\end{array}$} & \multicolumn{3}{|c|}{$\begin{array}{l}21 \text { million house holds with estimated } \\
\text { market size of Rs. } 1,300,000 \text { crores }\end{array}$} \\
\hline $\begin{array}{l}\text { Market } \\
\text { Potential }\end{array}$ & \multicolumn{2}{|c|}{$\begin{array}{l}\text { Over served and } \\
\text { demand languishing }\end{array}$} & \multicolumn{2}{|c|}{$\begin{array}{l}\text { Traditionally small } \\
\text { developers and new } \\
\text { focus of many large } \\
\text { developers }\end{array}$} & \multicolumn{3}{|c|}{$\begin{array}{l}\text { Under served and few entrants are over } \\
\text { sold }\end{array}$} \\
\hline
\end{tabular}

\section{IMPORTANCE OF THE STUDY}

Since not much research work has been done in the area of housing finance provided by various types of bank from the customers' point of view, it was decided to undertake one such study in Greater Vishakhapatnam city which is the fastest growing city in Andhra Pradesh India, as per the latest census data. It was decided to select one nationalized bank namely; LIC Housing Finance Ltd.

\section{LITERATURE REVIEW}

The issue of housing and housing finance has been receiving increasing attention over the recent decade in the extant literature. There have been many studies revised on various observations on this area, few of these namely; housing is an essential element of life for most human beings polarized by Naik (1981). According to J.P. Sah (2011), "housing is not a static but a growing problem and it was cited in Manorama Year Book (1997)as the modern concept of housing does not limit the idea of housing merely to the provision of shelter and it is an in an integral part of overall policy improvements of human settlements and economic development. Krishnamachari (1980), has stated in the preamble of the National Housing Policy, shelter is a basic human need and as an intrinsic part of human settlement, is closely linked with the process of overall socio-economic development. Housing is an element of material culture, is one of such devices to overcome threats against physical elements to lives and serves as an important purpose by making the provision of shelter and portrays that housing is as an important precursor of the national business cycle. In this view Some empirical exercises made on importance of housing among others Satyanarayana (1987), India year Book (1988), Andra C. Ghent and Michael T. Owyang (2010), Despande (1975) ,Dr. C. Harichandran (1989), highlighted the magnitude of the housing problem in our country is so heavy, that it will require considerable passage of time for the country to offer a sweet home to every family in our nation. Chacko (1989) was of the opinion that housing shortage in India in 1981 was 21 million units. In the beginning of the 7th five year plan in 1985, it was put as 24.7 million units. MadhavRao et al. (1995) suggested a multifaceted housing difficulty like ours requires a concrete national attempt. Erwin Mlecnik etal. (2010) studied about the barriers and opportunities for the further diffusion of labels for highly energy efficient houses. The Major subsidised housing projects in developing countries specified by Richard Harris and Ceinwen Giles (2003) have done tremendous work on identified three phases in the evolution of international housing policy since 1945: public housing (1945-1960s), sites-and-services (19721980s), and market enabling (1980s-present). As 
cited by Tiwari (2013), Housing finance in India has grown at a rapid pace during the last two decades.

\section{OBJECTIVES OF THE STUDY}

The following g objectives of the study are as under:

i. To study the customers' satisfaction levels towards housing finance banks in India.

ii. To understand why customers preferred the LIC Housing Finance Ltd. for home loan in India.

\section{HYPOTHESES}

The Hypotheses that are tested in this study are as follows:

i. There is no association between Age, Educational Qualification, Profession, Yearly Income of Respondents and the Amount of Loan Applied for.

ii. There is no association between the Age, Yearly Income, Profession, Educational Qualification of Respondents and Sanctioned Loan Amount.

iii. There is no association between Days taken for Sanctioned Loan and Type of Banks.

\section{METHODOLOGY}

The study is based on primary data as well as secondary data.

\section{PRIMARY DATA}

Primary data are collected through the responses of the customers through questionnaires which were specially prepared for this study. The questionnaire contained questions regarding the general and socioeconomic characteristics of the respondents such as age, religion, educational qualification, etc. and also about their reason for taking home loan, term, rate of interest, procedure etc. We conducted the pilot study by selecting seven respondents each banks including LIC Housing Finance Ltd. On the basis of their responses, some questions were modified and the modified questionnaire was finally canvassed among the 240 selected respondents. A sample size of 240 was used since 240 it was not possible to cover the whole universe consisting of all the customers. Among these 240 respondents were selected from LICHF Ltd. Primary data also included information collected by personal interview with managers of LIC Housing Finance Ltd.

\section{SECONDARY DATA}

There was extensive use of secondary information in the form of books, articles published in magazines, journals, newspaper, reports of LIC Housing Finance Ltd., websites, circulars, pamphlets of the banks, clippings etc.

\section{Period of study \& Sampling Technique}

The questionnaires were filled up during the period of April, 2014 to March 2015.The sample was selected using a convenient sampling.

\section{Statistical Techniques}

The collected data were scrutinized and edited. The edited data were analyzed using the software "Statistical Package for Social Sciences" (SPSS) and meaningful conclusion were arrived by constructing simple and two-way tables and by using statistical techniques like chi-square test. Simple table were constructed for analyzing the general information of the sample. Two-Way table were constructed for the comparative analysis and to know the relationship between two factors. At last the associations between different variables were tested by using the chi-square test.

\section{LIMITATIONS OF THE STUDY}

This research study was time bound and due to this only a few aspects of the problem were taken up in it.

\section{ANALYSYS OF CUSTOMER SATISFACTION}

The survey findings with respect to the level of customer satisfaction with various aspects can be shown in the following table. 
International Journal of Trend in Scientific Research and Development (IJTSRD) ISSN: 2456-6470

Table 3 Level of Customers' Satisfaction with Various Aspects

\begin{tabular}{|l|l|l|l|l|}
\hline SNo. & Particular & $\begin{array}{l}\text { Total Number of } \\
\text { Respondents (N) }\end{array}$ & $\begin{array}{l}\text { Weighted } \\
\text { Sum }\end{array}$ & $\begin{array}{l}\text { Average Level } \\
\text { of Satisfaction }\end{array}$ \\
\hline 1. & $\begin{array}{l}\text { Promptness of the } \\
\text { sanctioning of Loan }\end{array}$ & 240 & 476 & 3.47 \\
\hline 2. & $\begin{array}{l}\text { Promptness in disbursement } \\
\text { Safety-security- Privacy }\end{array}$ & 240 & 385 & 2.67 \\
\hline 3. & Loan Availability & 240 & 427 & 3.03 \\
\hline 4. & $\begin{array}{l}\text { The service quality } \\
\text { loan process }\end{array}$ & 240 & 467 & 3.41 \\
\hline 5. & $\begin{array}{l}\text { Cooperation of Staff } \\
\text { Dacumentation }\end{array}$ & 240 & 416 & 3.02 \\
\hline 7. & 240 & 468 & 3.41 \\
\hline 8. & Guarantee & 240 & 355 & 2.62 \\
\hline 9. & Security & 240 & 342 & 2.09 \\
\hline 10. & Rate of Interest & 240 & 279 & 2.14 \\
\hline 11. & EMI & 344 & 0.99 \\
\hline 12. & & 409 & 2.16 \\
\hline
\end{tabular}

Some of the respondents were requested to answer whether they know all the features of and LIC Housing Finance Ltd Whether they ever taken the Housing finance facilities from LIC Housing Finance Ltd.

Table 4 Knowledge of Features of LIC Housing Finance Ltd

\begin{tabular}{|l|l|l|l|}
\hline SNo. & Knowledge about the LICHFL & No. of Respondents & Percentage \\
\hline 1 & Yes & 140 & 58.33 \\
\hline 2 & No & 100 & 41.67 \\
\hline 3 & Total & 240 & 100.00 \\
\hline
\end{tabular}

Table 5 Suggestions to Improve Service Quality of LIC Housing Finance Ltd

\begin{tabular}{|l|l|l|l|}
\hline SNo. & Suggestions & Number of Response & $(\%)$ \\
\hline 1. & Fast Sanction & 135 & 56.25 \\
\hline 2. & Fast Disbursement & 110 & 45.8 \\
\hline 3. & Full Staff support & 85 & 35.42 \\
\hline 4. & No Guarantors need & 163 & 67.92 \\
\hline 5. & Less Documentation & 185 & 77.08 \\
\hline 6. & Less Interest Rate & 146 & 60.88 \\
\hline
\end{tabular}


International Journal of Trend in Scientific Research and Development (IJTSRD) ISSN: 2456-6470

\begin{tabular}{|l|l|l|l|}
\hline 7. & Less Hidden Charges & 157 & 65.42 \\
\hline 8. & Less EMI & 92 & 38.33 \\
\hline 9. & Quick Payment & 98 & 40.83 \\
\hline 10. & No Harassment & 49 & 20.42 \\
\hline
\end{tabular}

\section{CONCLUSION}

The waiver of pre-payment penalty charges has increased rivalry among banks and housing finance companies, which the regulator fears will lead to a dilution in underwriting and appraisal standards. The housing finance market is expected to grow 35 percent and reach a size of Rs.2.05-2.1 trillion by the end of the current fiscal, with banks having nearly a two-third share and housing finance companies the rest. To be sure, the central bank has always kept a close eye on real estate borrowing. In recent years, the Reserve Bank has introduced stricter provisioning norms as well as guidelines for banks to follow while approving loans. It has asked banks to adhere to prescribed loan-to-value ratios and ensure proper documentation of loans. Aggressive practices, such as the waiving of processing fees by big banks could be harmful for the industry.

The Indian housing finance market cannot be looked at independently of the government's role in the overall financial sector, which is nowadays characterized by a process of liberalization. However, the Indian government has tried, and is still trying, albeit to a lesser extent, to stimulate economic development by controlling interest rates and directing credit to priority sectors. Furthermore, private sector housing finance has been developed since 1977 and the creation of the National Housing Bank had helped the sector to develop further. In addition to specific guidelines and directions of HFCs, lending regulations, refinance facilities and the Home Loan Account scheme were set up with the particular intention of serving the small man. However, the intentions conflict with reality. The poor still face problems of accessibility, affordability and suitability of formal housing finance through HFCs. HFCs tend mainly to serve households with incomes above medium level, because the lending criteria (long-term credit, large loan size and tight methods of repayment) most closely fit the life-style of this income group.
Government control of the Indian housing finance market limits its further development. Financial subsidies, such as on interest rates and tax exemptions, generally benefit the better off. It would be wise to stop giving subsidies such as tax concessions and subsidies on interest rates, which are a burden on the financial system and the tax payers. An important lesson from the case described, which is probably beyond the Indian context, is that a credit mechanism which fits an incremental way of building should be developed instead of trying to fit the poor into the existing housing finance jacket. Such credit should be characterized by short- or medium-term credit, relatively small amounts and flexible repayment methods. In other words, an enabling strategy for the poor has more potential than encouraging the private sector to serve the small man. Reform of the housing finance schemes for middleand low-income households should take place simultaneously. If emphasis is put on the development of housing finance schemes for the poor and schemes for the middle-income households are neglected, middle-class groups will probably appropriate the schemes meant for the poor. Instead of interest subsidies on housing loans for the poor, one-time grants for households may be a better way to help them.

\section{REFERENCES}

1. Andra C. Ghent and Michael T. Owyang, Is housing the business cycle? Evidence from US cities, Journal of Urban Economics, 67(3), 2010, 336-35.

2. Anthony B. Sanders, Barriers to homeownership and housing quality: The impact of the international mortgage market, Journal of Housing Economics, 14(3), 2005, 147-152.

3. Chacko K.O., Annual General Body meeting of cooperative societies: A tutorial review, A Seminar on 'Housing Finance, 1989. 
4. Despande, Cheap and healthy house for the middle classes in India - United Book Corporation, Pune, 1975, 1-10.

5. Dr.HarichandranC. Housing Development Finance, Yojana Publication Division, New Delhi, 35, 1989,11-25.

6. Erwin Mlecnik, HenkVisscher and Anke van Hal, Barriers and opportunities for labels for highly energy-efficient houses, Journal of Energy Policy, 38(8), 2010, 4592-4603.

7. GopinathRao, C.H., Ownership of flats: Sai Ganesh offset printers - Santhome, Madras 4, 1988, $1-4$.

8. Krishnamachari S M, Mobilisation of Finance for Rural Housing, Yojana Publication Division, New Delhi, 26 1980, 16-18.

9. MadhavRao, A.G. Murthy and Annamalai G, Modem Trend in housing in Developing Countries, (Oxford and IBH Publishing Company, New Delhi, 1985, 341).

10. Naik D.D, Housing Finance Pamphlet 163, Commerce Publication, Bombay, 1981. pp.1, 12, 15 and 18.

11. Rangwala S.C., -Town Planning R.C. Patell, Charotar Book Stall, 1998, 51- 61.

12. Satyanarayana $\mathrm{C} P$, Housing rural poor and their living conditions, Gain Publishing House, Delhi, 1987, 15. 